\title{
MANAJEMEN BIROKRASI PROFESIONAL DALAM MENINGKATKAN PELAYANAN PUBLIK
}

\section{ABSTRACT}

Professional management of public services should be more goal-oriented paradigm of governance that is based on a new management approach, both theoretically and practically. Simultaneously, a paradigm of governance goal is expected to eliminate practices that Weberian bureaucracy is negative as hierarkhikal bureaucratic structures that result in operating cost is more expensive (high cost economy) than the benefits gained, the prevalence of red tape, lack of initiative and creativity of the apparatus, the growth of culture mediokratis (as opposed to meritocratic culture) and in-efficiency. Therefore, institutions of public service can be done by government and non-governmental organizations. If the government, the organization of government bureaucracy is the forefront of the organization (street level bureaucracy) related to public service. If the non-government, then shaped the organization of political parties, religious organizations, nongovernmental organizations and civil society organizations to another. Anyone pelayanananya institutional forms, the most important thing is how to provide assistance and facilities to the community in order to meet the needs and interests.

Keywords: Good Governance, Partnerships, Public Service.

\section{ABSTRAK}

Manajemen profesional pelayanan publik harus lebih berorientasi pada tujuan paradigma pemerintahan yang didasarkan pada pendekatan manajemen baru, baik secara teori maupun praktis. Secara bersamaan, paradigma dari tujuan pemerintahan diharapkan dapat menghilangkan praktek bahwa birokrasi Weberian adalah negatif seperti struktur birokrasi hierarkhikal yang menghasilkan biaya operasional lebih mahal (ekonomi biaya tinggi) daripada manfaat yang diperoleh, prevalensi birokrasi, kurangnya inisiatif dan kreativitas aparatur, pertumbuhan mediokratis budaya (sebagai lawan dari budaya meritokratis) dan in-efisiensi. Oleh karena itu, institusi pelayanan publik dapat dilakukan oleh pemerintah dan organisasi non-pemerintah. Jika pemerintah, organisasi birokrasi pemerintah adalah garis depan organisasi (jalan birokrasi tingkat) terkait dengan pelayanan publik. Jika non-pemerintah, kemudian membentuk organisasi partai politik, organisasi keagamaan, lembaga swadaya masyarakat dan organisasi masyarakat sipil yang lain. Siapapun pelayanananya bentuk kelembagaan, hal yang paling penting adalah bagaimana memberikan bantuan dan kemudahan kepada masyarakat dalam rangka memenuhi kebutuhan dan kepentingan.

Kata kunci: Good Governance, Kemitraan, Pelayanan Publik. 



\section{A. PENDAHULUAN}

Kecenderungan birokrasi dan birokratisasi pada masyarakat modern benar-benar memprihatinkan, sehingga digambarkan adanya ramalan mengenai makin menggejalanya dan berkembangnya praktek-praktek birokrasi yang paling rasionalpun, tidak bisa lagi dianggap sebagai kabar menggembirakan, melainkan justru merupakan pertanda malapetaka dan bencana baru yang menakutkan (Blau dan Meyer, 2000).

Menurut Siagian (1994), misalnya; mengakui adanya patologi birokrasi. Hal itu dicirikan oleh kecenderungan patologi karena persepsi, perilaku dan gaya manajerial, masalah pengetahuan dan ketrampilan, tindakan melanggar hukum, keperilakuan, dan adanya situasi internal. Demikian juga Kartasasmita (1995) menyebutkan, bahwa birokrasi memiliki kecenderungan mengutamakan kepentingan sendiri (self serving), mempertahankan status-quo dan resisten terhadap perubahan, dan memusatkan kekuasaan. Hal inilah yang kemudian memunculkan kesan bahwa birokrasi cenderung lebih mementingkan prosedur daripada substansi, lamban dan menghambat kemajuan.

Menurut Islamy (1998:8), birokrasi di kebanyakan negara berkembang termasuk Indonesia cenderung bersifat patrimonialistik: tidak efesien, tidak efektif (over consuming and under producing), tidak obyektif, menjadi pemarah ketika berhadapan dengan kontrol dan kritik, tidak mengabdi pada kepentingan umum, tidak lagi menjadi alat rakyat tetapi telah menjadi instrumen penguasa dan sering tampil sebagai penguasa yang sangat otoritatif dan represif. Sebagaimana dijelaskan dalam beberapa hasil penelitian (Santoso, 1993; Thaba, 1996; Fatah, 1998), birokrasi di Indonesia ada kecenderungan berkembang kearah "parkinsonian", dimana terjadinya proses pertumbuhan jumlah personil dan pemekaran struktur dalam birokrasi secara tidak terkendali.

Pemekaran yang terjadi bukan karena tuntutan fungsi, tetapi semata-mata untuk memenuhi tuntutan struktur. Disamping itu, terdapat pula kecenderungann terjadinya birokrasi "orwellian" yakni proses pertumbuhan kekuasaan birokrasi atas masyarakat, sehingga kehidupan masyarakat menjadi dikendalikan oleh birokrasi. Akibatnya, birokrasi Indonesia semakin membesar (big bureaucracy) dan cenderung tidak efektif dan tidak efesien. Kondisi yang demikian, sangat sulit diharapkan birokrasi siap dan mampu melaksanakan kewenangan-kewenangan barunya secara optimal.

Meskipun sudah menjadi gejala yang sangat umum, ternyata pada setiap konteks sistem budaya masyarakat, secara empirik birokrasi dan birokratisasi terlihat dalam pola perilaku yang beragam. Gejala demikian menunjukkan bahwa birokrasi dan birokratisasi tidak pernah tampil dalam bentuk idealnya. Beberapa alasan, mengapa bentuk ideal birokrasi tidak nampak dalam praktek kerjanya antara lain: Pertama, manusia birokrasi tidak selalu berada (exist) hanya untuk organisasi. Kedua, birokrasi sendiri tidak kebal terhadap perubahan sosial. Ketiga, birokrasi dirancang untuk semua orang. Keempat, dalam kehidupan keseharian manusia birokrasi berbeda-beda dalam kecerdasan, kekuatan, pengabdian dan sebagainya, sehingga mereka tidak dapat saling dipertukarkan untuk peran dan fungsinya di dalam kinerja organisasi birokrasi.

Demikian dapat ditegaskan, bahwa ada kecenderungan bahwa beberapa indikator birokrasi lebih Berjaya hidup di dunia barat daripada di dunia timur. Hal ini dapat dipahami, karena di dunia barat birokrasi telah berkembang selama beberapa abad. Suatu misal pada abad pertengahan dan seterusnya, perkembangan birokrasi semakin dipacu dan di dukung oleh masyarakat industri. Oleh karena rasionalitas birokrasi cenderung berhubungan dengan gejala industrialisasi, maka banyak negara yang bercita-cita masyarakatnya menjadi masyarakat industri dan mengadopsi model birokrasi rasional di dalamnya. Namun demikian, bagi masyarakat yang sedang berkembang tidak semua kemanfaatan birokrasi rasional dapat dipetik dan dirasakan. Selain itu, birokrasi menghadapi krisis kepercayaan dari masyarakat, sehingga kecaman dan pesimisme muncul karena 
banyak anggota masyarakat merasakan bahwa berbagai pola tingkah laku yang merupakan kebiasaan dalam birokrasi tidak dapat mengikuti dan memenuhi tuntutan pembangunan dan perkembangan masyarakatnya.

Islamy (1998), menyebutkan adanya keadaan birokrasi publik di sektor pemerintahan, pendidikan dan kesehatan dan sebagainya berada dalam suatu kondisi yang dikenal dengan istilah organizational slack yang ditandai dengan menurunnya kualitas pelayanan yang diberikannya. Masyarakat pengguna pelayanan banyak mengeluhkan akan lambannya penanganan pemerintah atas masalah yang dihadapi dan bahkan mereka telah memberikan semacam public alarm agar pemerintah sebagai instansi yang paling berwenang, responsif terhadap semakin menurunnya kualitas pelayanan kepada masyarakat segera mengambil inisiatif yang cepat dan tepat untuk menanggulanginya.

Lebih lanjut Islamy (1998), terdapat pelbagai faktor yang menyebabkan birokrasi publik mengalami organizational slack yaitu antara lain pendekatan atau orientasi pelayanan yang kaku, visi pelayanan yang sempit, penguasaan terhadap administrative engineering yang tidak memadai, dan semakin bertambah gemuknya unit-unit birokrasi publik yang tidak difasilitasi dengan 3P (personalia, peralatan dan penganggaran) yang cukup dan handal (viable bureaucratic infrastructure). Akibatnya, aparat birokrasi publik menjadi lamban dan sering terjebak ke dalam kegiatan rutin, tidak responsif terhadap aspirasi dan kepentingan publik serta lemah beradaptasi terhadap perubahan yang terjadi di lingkungannya.

Sebagai konsekuensinya, perlu dipertanyakan mengenai posisi aparat pelayanan ketika berhadapan dengan masyarakat atau kliennya. Apakah birokrasi publik itu alat rakyat? Alat penguasa? Ataukah penguasa itu sendiri? Guna merespon kesan buruk birokrasi seperti itu, birokrasi perlu melakukan beberapa perubahan sikap dan perilakunya antara lain : (a) birokrasi harus lebih mengutamakan sifat pendekatan tugas yang diarahkan pada hal pengayoman dan pelayanan masyarakat; dan menghindarkan kesan pendekatan kekuasaan dan kewenangan; (b) birokrasi perlu melakukan penyempurnaan organisasi yang bercirikan organisasi modern, ramping, efektif dan efesien yang mampu membedakan antara tugas-tugas yang perlu ditangani dan yang tidak perlu ditangani (termasuk membagi tugas-tugas yang dapat diserahkan kepada masyarakat); (c) birokrasi harus mampu dan mau melakukan perubahan system dan prosedur kerjanya yang lebih berorientasi pada ciri-ciri organisasi modern yakni : pelayanan cepat, tepat, akurat, terbuka dengan tetap mempertahankan kualitas, efesi-ensi biaya dan ketepatan waktu; (d) birokrasi harus memposisikan diri sebagai fasilitator pelayan publik dari pada sebagai agen pembaharu pembangunan; (e) birokrasi harus mampu dan mau melakukan transformasi diri dari birokrasi yang kinerjanya kaku (rigid) menjadi organisasi birokrasi yang strukturnya lebih desentralistis, inovatif, fleksibel dan responsif.

Bertitik tolok dari pandangan ini, dapat disimpulkan bahwa organisasi birokrasi yang mampu memberikan pelayanan publik secara efektif dan efesien kepada masyarakat, salah satunya jika strukturnya lebih terdesentralisasi daripada tersentralisasi. Dengan struktur yang terdesentralisasi diharapkan akan lebih mudah mengantisipasi kebutuhan dan kepentingan yang diperlukan oleh masyarakat, sehingga dengan cepat birokrasi menyediakan pelayanannya sesuai yang diharapkan masyarakat pelanggannya. Sedangkan dalam konteks persyaratan budaya organisasi birokrasi, perlu dipersiapkan tenaga kerja atau aparat yang benar-benar memiliki kemampuan (capabality), memiliki loyalitas kepentingan (competency), dan memiliki keterkaitan kepentingan (consistency atau coherency).

Menyadari akan hal tersebut, maka untuk merealisasikan kriteria ini Pemerintah sudah seharusnya segera menyediakan dan mempersiapkan tenaga kerja birokrasi professional yang mampu menguasai teknik-teknik manajemen pemerintahan yang tidak hanya berorientasi pada peraturan (rule oriented) tetapi juga pada pencapaian tujuan (goal oriented).

Menurut Johnson (1991), istilah "professional" dan "professionalisasi", dapat ditinjau dari beberapa sudut pandang. Pertama, 
dipergunakan untuk menunjuk pada perubahan besar dalam struktur pekerjaan, dengan jumlah pekerjaan-pekerjaan professional, atau bahkan pekerjaan-pekerjaan halus (white collar jobs) yang meningkat secara relative dibandingkan dengan pekerjaan-pekerjaan lainnya, baik sebagai akibat perluasan kelompok pekerjaan yang sudah ada ataupun sebagai akibat munculnya pekerjaan-pekerjaan baru di bidang jasa. Kedua, dipergunakan dalam arti yang hampir sama dengan peningkatan jumlah asosiasi pekerjaan yang mengupayakan adanya pengaturan rekrutmen dan praktek dalam bidang pekerjaan tertentu. Ketiga, memandang professionalisasi sebagai suatu proses yang jauh lebih rumit yang menunjuk pada suatu pekerjaan dengan sejumlah atribut prinsip-prinsip professional yang merupakan unsur-unsur pokok profesionalisme. Keempat, menunjuk pada suatu proses dengan urutan yang tetap, yaitu suatu pekerjaan dengan tahap-tahap perubahan organisatoris yang dapat diramalkan menuju bentuk akhir profesionalisme.

Terkait dengan penyelenggaraan pemerintahan, birokrasi sebagai ujung tombak pelaksana pelayanan publik mencakup berbagai program-program pembangunan dan kebijaksanaan-kebijaksanaan pemerintah. Tetapi dalam kenyataannya, birokrasi yang dimaksudkan untuk melaksanakan tugastugas umum pemerintahan dan pembangunan tersebut, seringkali diartikulasikan berbeda oleh masyarakat. Birokrasi di dalam menyelenggarakan tugas pemerintahan dan pembangunan (termasuk di dalamnya penyelenggaraan pelayanan publik) diberi kesan adanya proses panjang dan berbelit-belit apabila masyarakat menyelesaikan urusannya berkaitan dengan pelayanan aparatur pemerintahan. Akibatnya, birokrasi selalu mendapatkan citra negatif yang tidak menguntungkan bagi perkembangan birokrasi itu sendiri (khususnya dalam hal pelayanan publik).

\section{B. STRATEGI PENDEKATAN}

Strategi manajemen birokrasi profesional dalam pelayanan publik ini ditandai dengan beberapa karakteristik antara lain: Pertama, perubahan yang besar pada orientasi administrasi negara tradisional menuju ke perhatian yang lebih besar pada pencapaian hasil dan pertanggung jawaban pribadi pimpinan. Kedua, keinginan untuk keluar dari birokrasi klasik dan menjadikan organisasi, pegawai, masa pengabdian dan kondisi pekerjaan yang lebih luwes. Ketiga, tujuan organisasi dan individu pegawai disusun secara jelas sehingga memungkinkan dibuatkannya tolok ukur prestasi lewat indikator kinerjanya masing-masing, termasuk pula sistem evaluasi program-programnya. Keempat, staf pimpinan yang senior dapat memiliki komitmen politik kepada pemerintah yang ada, dan dapat pula bersikap non partisan dan netral. Kelima, fungsi-fungsi pemerintah bisa dinilai lewat uji pasar (market test) seperti misalnya dikontrakkan pada pihak ketiga tanpa harus disediakan atau ditangani sendiri oleh pemerintah. Keenam, mengurangi peranperan pemerintah misalnya lewat kegiatan privatisasi. Ketujuh, birokrasi harus steril dari akomodasi politik yang menghambat efektivitas pemerintahan. Kedelapan, rekruitmen dan penempatan pejabat birokrasi yang bebas dari kolusi, korupsi dan nepotism.

Penerapan pendekatan manajemen profesional pada sektor publik telah banyak disuarakan para pakar dengan berbagai label, misalnya dengan nama "managerialism" oleh Pollitt (1990), "new public management" oleh Hood (1991), "market based public administration" oleh Lan dan Rosenbloom (1992), dan "entrepreneurial government/reinventing Government" oleh Osborn dan Gaebler (1992). Apapun label yang dipergunakan, yang jelas pendekatan manajemen profesional ini telah merubah orientasi fokus peran dan fungsi birokrasi dalam pemerintahan yang semula lebih mementingkan "process" menuju ke "product", atau dari " rule governance" menuju ke "goal governance".

\section{KOMPARASI RULE GOVERNANCE DAN GOAL GOVERNANCE}

Perlu disadari bahwa, dalam perdebatan teoritis dari kedua kutub orientasi ini, baik rule governance maupun goal governance memiliki 
segi kelemahan dan kelebihannya masingmasing. Kelemahan rule governance, misalnya, dianggap mempunyai penerapan peraturan yang kaku, bercirikan struktural hierarkhikal, pengawasan yang ketat, bersifat impersonal, dan sebagainya, sehingga menjadikan birokrasi sebagai "mesin rasional" yang menciptakan perilaku aparat yang formal dan robotic yang kurang peka terhadap nilai-nilai kemanusiaan dan lingkungan sosialnya.

Akibat dari struktur birokrasi yang terlalu rasional bisa menimbulkan hal-hal yang sifatnya disfungsional, in-efesiensi dan bahkan konflik dengan masyarakat yang dilayani, karena sifat impersonal aparat birokrasi dalam memberikan pelayanan kepada masyarakatnya. Demikian pula, aturan-aturan (rules) sebagai sarana untuk mencapai tujuan seringkali berubah menjadi tujuan itu sendiri. Kelebihannya, menunjukkan semakin tingginya tertib administrasi yang dicapai oleh birokrasi publik.

Adapun kelebihan goal governance yaitu meletakkan fokus utamanya pada "the achievement of result and taking individual responsibility for their achievement". Tetapi ia juga memiliki kelemahan apabila prinsip-prinsip manajemen baru itu hendak diterapkan di sektor publik. Misalnya, sampai sekarang masih terjadi diskursus yang seru terhadap 10 prinsip dalam entrepreneurial governmentnya Osborn dan Gaebler (1992) yang mereka kemukakan dalam uraian yang sangat provokatif yaitu Reinventing Government.

Konsep pemerintahan entrepreneur Osborn dan Gaebler yang mencoba menemukan nilai-nilai baru (re-inventing) di bidang pemerintahan ternyata menurut Painter (1994) mempunyai kekuatan dan sekaligus kelemahan. Kritik Painter terhadap konsep pemerintahan entrepreneur adalah bahwa ia terlalu bias pada "new administrative values" yang lebih banyak menitik beratkan pada orientasi goal governance dengan meminggirkan nilai-nilai administrasi klasik yang sebenarnya masih potensial yang berbasis pada rule governance. Painter menyebutnya bukannya reinventing government melainkan pemerintahan yang sudah dalam keadaan tertinggal (abandoning government), karena
Osborn dan Gaebler sebenarnya telah menghapus atau setidak-tidaknya telah membelotkan nilai-nilai pemerintahan. Padahal kedua nilai tersebut (lama dan baru) bisa disatu padukan.

Kritik lain, misalnya dari Pollitt (dalam Hughes, 1994) yang meragukan penerapan prinsip-prinsip entrepreneurship di sektor publik. Setidak-tidaknya ada dua hal yang melemahkan konsep tersebut dengan mengatakan : "First, the provider/consumer transactions in the public services tend to be notably more complex than those faced by the costumer in a normal market; and second, public service consumers are never merely consumers, they are always citizens too, and they has a set of unique implications for the transactions" (Pertama, transaksi, provider/konsumer dalam pelayanan publik cenderung berada pada sesuatu yang khusus dan lebih komplek daripada berhadapan dengan pelanggan di pasar yang normal; Kedua, pengguna pelayanan publik tidak hanya konsumer saja, mereka juga termasuk warga negara lain, dan mereka adalah bagian yang unik dari implikasi suatu transaksi).

Sehubungan dengan itu, menurut Hughes (1994) diperlukan adanya repositioning dengan menyusun agenda kebijakan reformasi administrasi Negara dengan mensinergikan orientasi rule governance dan goal governance. Hughes mengatakan: the best parts of the old model professionalism, impartiality, high ethical standards, the absence of corruption can be maintained, along with the improved performance a managerial model premises" (bagian terbaik dari model profesionalisme lama adalah sikap yang adil, standard etika yang tinggi, tingkat korupsi yang dapat dipantau, bersamaan dengan bentuk dasar pemikiran model manajerialnya).

Memahami perdebatan persoalan tatanan dan pertikaian (order and conflict) seperti diatas, hingga kinipun para teoritisi sosiologipolitik sering membandingkannya dengan perdebatan hubungan antara struktur dengan tindakan. Berkenaan dengan persoalan ini, Sharrock dan Watson (1988) mengemukakan sebagai berikut; "What is the relationship between structure and agency? The two seem 
inimical: structure apparently means givenness, constraint, stability, whilst agency seemingly implies creativity, autonomy, fluidity. How, then, do structure and agency relate in society: is it primarily one or the other? Does emphasis on structure marginalize or eliminate agency, does emphasis on agency dispose of structure?".

Tampaknya, hubungan antara struktur dengan tindakan cenderung digambarkan sebagai bersifat antagonistik. Struktur sering digambarkan sebagai suatu ketentuan, kekuatan penghambat, dan kestabilan. Sedangkan tindakan cenderung menampakkan daya cipta, otonomi, dan ketidak stabilan. Karena itu, penting untuk diajukan pertanyaan. Manakah yang lebih mendasar, struktur atau tindakan? Benarkan bila penekanan diberikan kepada struktur berarti menghilangkan atau meminggirkan tindakan? Sebaliknya, benarkan bila penekanan diberikan kepada tindakan berarti membuang struktur begitu saja?

Benarkah bahwa tertib yang berlangsung dalam birokrasi selalu bersifat impersonal? Benarkan bahwa para pejabat birokrasi hanya tunduk kepada suatu tatanan yang menjadi kiblat bagi segala tindakannya?. Mengapa birokrasi cenderung bertindak berbeda pada setting ruang dan waktu yang berbeda? Apakah perubahan yang dilakukan oleh birokrasi sesuai dengan fungsi reformasi yang dikehendaki oleh masyarakat banyak, ataukah sekedar formalitas sebagai kewajiban struktural yang cenderung statusquo; atau hanya sebagai mesin alat penggerak untuk memanipulasi dan memobilisasi rakyat agar tunduk pada kekuasaan birokrasi (machine bureaucracy)?.

Pertanyaan-pertanyaan ini antara lain dapat dijawab melalui pandangan kelompok: aliran strukturalis, aliran strukural-konflik, dan aliran strukturasi. Aliran strukturalis (Marx, 1942; Dahrendorf, 1959), berpandangan bahwa kekuasaan (birokrasi) adalah sebagai fasilitas atau sumber sosial yang dapat dipakai untuk mencapai tujuan bersama. Fungsi sosial dari kekuasaan adalah untuk memelihara ketertiban dan keseimbangan dalam masyarakat. Kekuasaan sebagai atribut utama dalam sistem sosial berwujud kepemimpinan yang bertanggung jawab, tetapi juga berbentuk keputusan-keputusan yang mengikat bagi semua golongan masyarakat. Jadi kekuasaan adalah sarana bagi tercapainya tujuan-tujuan masyarakat secara keseluruhan.

Atas dasar itu, menurut pandangan strukturalis, konsentrasi kekuasaan adalah syah selama masyarakat memang menghendakinya. Kritik terhadap hampiran ini adalah karena kaum strukturalis terlalu menitik beratkan pada struktur yang statis (statusquo) dengan mengabaikan proses perubahan sosial yang terjadi, serta ketidak mampuannya mengatasi konflik secara efektif (Cohen, 1968; Gouldner, 1970; Abrahamson, 1978). Implikasi hampiran strukturalis ini terhadap fenomena birokrasi profesional menunjukkan bahwa perubahan tindakan birokrasi merupakan gerakan moral masyarakat yang menghendaki adanya suatu perubahan paradigma kinerja birokrasi.

Berbeda halnya dengan pandangan aliran struktural-konflik (Gramsci, Baran, Coser, dalam Turner, 1974); kelompok yang satu ini justru melihat tindakan birokrasi sebagai suatu fakta sosial yang banyak diwarnai oleh dominasi politik, eksploitasi sosial, dan perkembangan ekonomi. Dominasi politik ditandai dengan suasana paksaan (coercion) yang menimbulkan intimidasi, propaganda dan indoktrinasi. Dominasi sosial ditandai dengan supremasi golongan/ras/budaya yang menyebabkan suasana hegemoni. Sedangkan dominasi ekonomi ditandai oleh eksploitasi akibat ketimpangan distribusi alat produksi antara kepentingan kelas borjuasi dengan proletar.

Implikasi pandangan aliran strukturalis konflik ini terhadap fenomena birokrasi profesional menunjukkan bahwa perubahan paradigma yang dilakukan oleh birokrasi justru akan menimbulkan konflik baru (new conflict) dalam tatanan kenegaraan, pemerintahan dan kemasyarakatan.

Menurut aliran strukturasi Giddens (dalam Baert, 1998), mencoba mencari hubungan antara struktur dan aktor. Kelompok strukturasionis ini tidak memandang struktur dan aktor atau agen sebagai dua hal yang dikotomis sehingga menghasilkan dualisme struktur; sebaliknya dua hal tersebut saling berhubungan secara dialektis dan kontinuum 
sehingga menghasilkan dualitas struktur. Aktor atau agen menurut pandangan aliran ini adalah partisipan yang aktif dalam mengkonstruksi kehidupan sosial, setidak-tidaknya menjadi tuan atas nasibnya sendiri.

Setiap tindakan manusia selalu mempunyai tujuan. Ini berarti bahwa aktor secara rutin dan diam-diam memonitor apa yang sedang ia lakukan, sebagaimana reaksi orang terhadap tindakannya dan lingkungan dimana ia melakukan aktivitas tersebut. Sedangkan struktur, selain dapat membatasi aktivitas manusia (constraining) tetapi juga memberikan kebebasan bertindak (enabling) kepada manusia. Dualitas struktur melihat kekuasaan (birokrasi) sebagai simuka janus (the janus face of power) yang berfungsi sebagai alat analisis kehidupan sosial yang penting, terutama mengenai hubungan antara tindakan manusia dan struktur. Dualitas struktur menganalisis bagaimana tindakan-tindakan aktor sosial diproduksi dan juga bagaimana struktur secara terus menerus di reproduksi dalam kegiatan-kegiatan si aktor sosial sepanjang waktu dan ruang yang sangat luas.

Teori strukturasi ini tidak luput dari kritik. Beberapa kritik yang sering dikemukakan terhadap aliran strukturasi antara lain : (a) masih sedikitnya bukti empirik yang bisa memperkuat validitas teori ini; Bukan aktor atau agen merubah struktur, tetapi justru struktur merubah aktor atau agen; (b) Giddens dipandang gagal menjelaskan fenomena konflik; (c) diragukan keaslian, kedalaman, kejelasan analitik dan konsistensi internalnya (fallacy of perspectivism), karena berasal dari pinjaman berbagai teori lain; dan (d) dicurigai karena pendirian politiknya cenderung mendukung statusquo.

Implikasi hampiran strukturasi ini terhadap fenomena birokrasi professional diharapkan akan berdampak positif dalam upaya menciptakan kejelasan pembagian konsep ruang publik (public sphere) dan ruang pribadi (private sphere) dalam pembaharuan perubahan orientasi tindakan birokrasi. Jawaban teoritis tersebut diatas sengaja penulis ajukan untuk memancing wacana dan emosi para pembaca apakah strategi manajemen birokrasi profesional masih dimungkinkan untuk dilaksanakan atau tidak di Negara Republik Indonesia ini? Jika ya, maka akan lahir puteraputeri bangsa yang terbaik dari yang terbaik (best for the best) seperti yang diharapkan selama ini.

\section{KESIMPULAN}

Mencermati uraian terdahulu tentang manajemen birokrasi profesional, kaitannya dengan kecenderungan merosotnya pelayanan publik di berbagai Negara-negara Dunia Ketiga, termasuk Indonesia dapat disimpulkan bahwa, pada masa revolusi industri di Eropa, profesionalisme yang demikian itu sesuai dengan realitas. Tetapi menjadikan fenomena historis yang sangat konteksual ini sebagai suatu paradigma untuk masa kini nampaknya tidak lebih dari sebuah mitos. Profesionalisme sejati telah memudar, dan kaum professional seperti yang dapat kita saksikan telah bertingkah laku moneymindedness. Kemadirian mereka pun semakin terdesak oleh birokratisasi pelayanan dan oleh berbagai pengawasan. Betapa tidak, lembaga profesionalisme telah mengalami banyak kemerosotan peran dalam masyarakat.

Secara garis besar simpulan yang ditarik untuk mengatasi persoalan kemunduran birok-rasi dalam hal pelayanan publik sebagai "solusi" strateginya meliputi : (1) merubah persepsi dan paradigma birokrasi mengenai konsep pelayanan; (2) adanya kebijakan publik yang lebih mengutamakan kepentingan publik dan pelayanan publik dibanding dengan kepentingan penguasa atau elit tertentu; (3) unsur pemerintah, privat dan masyarakat harus merupakan all together yang sinergi; (4) adanya peraturan daerah yang mampu menjelaskan standar minimal pelayanan publik dan sanksi yang akan diberikan; (5) adanya mekanisme pengawasan sosial yang jelas mengenai pelayanan publik antara birokrat dan masyarakat yang dilayani; (6) adanya kepemimpinan yang kuat dalam melaksanakan komitmen pelayanan publik; (7) adanya pembaharuan di bidang sistem administrasi publik; dan (8) adanya upaya untuk memberdayakan masyarakat (empowerment) secara terus menerus dan demokratis. 


\section{DAFTAR PUSTAKA}

Baert, Patrick, 1998, Social Theory Twentieth Century, Cambridge : Polity Press.

Bevir, Mark, 2011, "Democratic Governance: A Genealogy", Local Government Studies, Vol. 37(1), February 2011, (pp 317)

Blau, Peter.M dan Meyer, Marshall.W, 2000, Birokrasi Dalam Masyarakat Modern, Terjemahan, Jakarta : Prestasi Pustakaraya.

Chisholm, M., 2010, "Emerging Realities of Local Government Reorganisation", Public Money Management, 30, (pp. 143150)

Giddens, Anthony, 1995, The Constitution of Society, Cambridge : Polity Press.

Hariandja Denny, BC, 1999, Birokrasi Nan Pongah: Belajar dari Kegagalan Orde Baru, Yogyakarta: Kanisius.

Heckscher, Charles and Donnellon, Anne (ed), 1994, The Post Bureaucratic Organization: New Perspectives on Organizational Change, London, New Delhi : Sage Publications.

Henderson, Keith M, and Dwivedi,O.P, 1999, Bureaucracy and The Alternatives in World Perspective, London : Macmilland Press Ltd.

Kaisiepo, Manuel, 1987, "Dari Kepolitikan Birokratik ke Korporatisme Negara: Birokrasi dan Politik Indonesia", Jurnal Politik 2, Jakarta : Gramedia.
Osborn, David and Gaebler, Ted, 1996, Mewirausahakan Birokrasi: Reinventing Government, Mentransformasi Semangat Wirausaha Ke Dalam Sektor publik, Jakarta : Pustaka Binaman Pressindo.

Osborne, David dan Plastrik, Peter, 2000, Memangkas Birokrasi: Lima Strategi Menuju Pemerintahan Wirausaha, Jakarta : PPM.

Putra, Fadillah dan Arif, Saiful, 2001, Kapitalisme Birokrasi: Kritik Reinventing Government Osborne Gaebler, Yogyakarta : LKiS.

Santoso, Priyo Budi, 1993, Birokrasi Pemerintah Orde Baru, Perspektif Kultural dan Struktural, Jakarta, Raja Grafindo Persada.

Setiono, Budi, 2002, Jaring Birokrasi: Tinjauan dari Aspek Politik dan Administrasi, Bekasi : Gugus Press.

Siagian, SP, 1994, Patologi Birokrasi: Analisis, Identifikasi Dan Terapinya, Jakarta : Ghalia Indonesia.

Sumoprawiro, Hariyoso,2002, Pembaruan Birokrasi Dan Kebijaksanaan Publik, Jakarta : Peradaban.

Tjokrowinoto, Moeljarto,2001, Birokrasi dalam Polemik, Saiful Arif (editor), Yogyakarta: Pustaka Pelajar.

Thoha, Miftah dan Dharma, Agus (editor), 1999, Menyoal Birokrasi Publik, Jakarta : Balai Pustaka. 